Int. J. Morphol.,

30(3):1023-1028, 2012.

\title{
Condylar Resorption After Orthognathic Surgery: A Systematic Review
}

\author{
Reabsorción Condilar Después de Cirugía Ortognática: Una Revisión Sistemática
}

\author{
"Paulo Hemerson de Moraes; " Célia Marisa Rizzati-Barbosa; ${ }^{* * *}$ Sergio Olate; \\ ${ }^{* * * * *}$ Roger Willian Fernandes Moreira \& ${ }^{* * * *}$ Márcio de Moraes
}

\begin{abstract}
DE MORAES, P. H.; RIZZATI-BARBOSA, C. M.; OLATE, S.; MOREIRA, R. W. F. \& DE MORAES, M. Condylar resorption after orthognathic surgery: A systematic review. Int. J. Morphol., 30(3):1023-1028, 2012.

SUMMARY: The aim of this research was to evaluate the risk factors related to condylar resorption (CR) after orthognathic surgery. Was realized a systematic review with a search of the literature performed in the electronic databases PubMed, MedLine, Ovid, Cochrane Library for current evidence in the world literature as conducted, and relevant articles were selected in according to inclusion and exclusion criteria and the findings were compared. Eight papers, (follow-up 12 months to 69 months) were including. A sample of 2567 patient with mandible or bi maxillary surgery with an age range from 14 to 46 year old was observed. In 137 patients (5.3\%) CR was observed, with a $97.6 \%$ (122) female. CR was related to 118 cases with mandibular deficiencies with high mandibular plane (advancement surgery). CR were present principally in bi maxillary surgery with a 103 cases (75.2\%) and only two papers show any analysis to the relation with TMJ dysfunction. Current evidence in CR is poor but supports those female patients with mandibular deficiency and high mandibular plane angle submitted to bi maxillary surgery with change in occlusal plane (counterclockwise) are associated with condylar resorption after orthognathic surgery.
\end{abstract}

KEY WORDS: Condylar resorption; Orthognathic surgery; TMJ dysfunction.

\section{INTRODUCTION}

In 1978, Phillips \& Bell first reported bilateral atrophy of the mandibular condyles after bilateral sagittal split ramus osteotomy (BSSRO) for mandibular advancement. Although a definitive cause could not be established, they hypothesized that a biomechanical phenomenon based on increased muscle tension was the most likely causative mechanism. The incidence of condylar resorption after orthognathic surgery is reported to range from $1 \%$ to $31 \%$ (de Mol van Otterloo et al., 1993; Hwang et al., 2000a; Hoppenrejis et al., 1998; O'Ryan \& Epker, 1984) and the first radiologic signs is present postoperatively in the 6th or posterior months (O’Ryan \& Epker).

Condylar resorption (CR) or condylysis can be defined as progressive alteration of condylar shape with a decrease in mass. As a result, most patients exhibit a decrease in posterior face height, retrognathism and progressive anterior open bite with clockwise rotation of the mandible.
CR may be described as osteoarthrosis and can be subdivided into primary (idiopathic) and secondary (de Bont \& Stegenga, 1993). The degenerative changes of secondary osteoarthrosis are caused by joint afflictions, such as rheumatoid arthritis, or by alteration of joint anatomy following excessive traumatic loading of the temporomandibular joint (TMJ) with or without disc displacement (de Bont \& Stegenga). They can also result from condylar resorption after orthognathic surgery.

In the past, many studies on this subject have been published (Phillips \& Bell; O’Ryan \& Epker; Arnett \& Tamborello, 1990; Arnett et al., 1996a, 1996b; Bouwman et al., 1994; Merkx \& Van Damme, 1994; Scheerlinck et al., 1994). These papers have reported clinical and radiological features of condylar resorption and proposed contributing factors. This research show that predisposing patient factors are preoperative TMJ dysfunction, the age 
close range from 15 to 35 years, females presenting a high mandibular plane angle with mandibular hypoplasia and a small posterior-to-anterior facial height ratio (Hoppenreijs et al.; Kerstens et al.; Arnett et al., 1996a, 1996b; Huang et al., 1997; Hwang et al., 2000b; Moore et al., 1991). A posterior inclined condylar neck has been considered another contributing factor (Hwang et al., 2000a, 2000b; Hoppenreijs $e t a l$.). For other hand, surgical factors how mandibular advancement, maxillary impaction, mandibular autorotation, and bi maxillary surgery can induce condylar resorption. In fact, the incidence of CR is significantly higher after bi maxillary osteotomy (Hoppenreijs et al.).

The aim of this study was a systematic review of the literature to evaluate the current evidence identifying risk factors on condylar resorption after orthognathic surgery.

\section{MATERIAL AND METHOD}

Search strategy. This search involved the online medical performed in the electronic databases PubMed, MedLine, Ovid and Cochrane Library from January 1978 to August 2010. The free text words and MeSH terms were used. The following keywords were used to identify relevant publications: condylar resorption, progressive condylar resorption, idiopathic resorption, condylar atrophy, dysfunctional remodeling, avascular necrosis, osteonecrosis and condylysis. The heading sequence of the MeSH terms used ("orthognathic surgery" [MeSH]") AND ("condylar resorption" OR "progressive condylar resorption" OR "idiopathic resorption" "OR "condylar atrophy" OR "dysfunctional remodeling" OR "avascular necrosis" OR "osteonecrosis" OR "condylysis") was selected. A search for previous systematic review or metaanalysis on the CR after orthognathic surgery yielded no result.
The abstract of each article was reviewed and full articles relevant to condylar resorption after orthognathic surgery were retrieved. A search of reference lists of the articles retrieved was also performed and any relevant articles were included.

Thirty four papers resulted from this search. Two independent observers (PHM and CMRB) reviewed the abstracts from all the paper initially selected; for final research was including the paper related to the following criteria: Full text in English language; human clinical trials; randomized, clinical trials, prospective multicenter articles, or prospective clinical trial; Retrospective studies aimed at identifying risk factors for resorption condylar; Followup of 1 year or longer; No individual or series case report, descriptive studies, opinion articles, or abstracts; articles with less than 10 patients were evaluated; and no syndromes or medically compromised patients, and no diseases.

The full text articles were obtained and analyzed by the same two independent observers. In this second revision were applied the inclusion and exclusion criteria again and a definitive list of papers was identified for extraction of data.

Articles considered worthy by both observers were included. Where only one observer supported inclusion, a decision was made based on discussion between the two observers considering the inclusion criteria. The results were compared and the data were analyzed using the index of inter-rater reliability (Cohen's Kappa).

\section{RESULTS}

The search strategy resulted in 34 papers on condylar resorption after orthognathic surgery. After selection

Table I. Review of selected papers reporting CR after orthognathic surgery.

\begin{tabular}{|c|c|c|c|c|c|c|}
\hline Authors & Year & $\begin{array}{l}\text { Mandibular } \\
\text { prognathism }\end{array}$ & $\begin{array}{c}\text { Mandibular } \\
\text { prognathism } \\
\text { with open bite }\end{array}$ & $\begin{array}{l}\text { Mandibular deficiency, } \\
\text { low/normal mandibular } \\
\text { plane angle }\end{array}$ & $\begin{array}{l}\text { Relative mandibular } \\
\text { deficiency }\end{array}$ & $\begin{array}{l}\text { Absolute mandibular } \\
\text { deficiency, high } \\
\text { mandibular plane angle }\end{array}$ \\
\hline Kerstens et al. & 1990 & 14 & 20 & 76 & 47 & $49(12-\mathrm{CR})$ \\
\hline Merkx \& Van Damme & 1994 & $\mathrm{U}$ & $\mathrm{U}$ & $\mathrm{U}$ & $\mathrm{U}$ & $7(7-\mathrm{CR})^{*}$ \\
\hline De Clerq et al. & 1994 & $\mathrm{U}$ & $\mathrm{U}$ & $\mathrm{U}$ & $\mathrm{U}$ & $29(9-\mathrm{CR})$ \\
\hline Scheerlinck et al. & 1994 & - & - & $103(8-\mathrm{CR})^{* *}$ & - & - \\
\hline Bouwman et al. & 1994 & 134 & 76 & 549 & 108 & $158(33-\mathrm{CR})$ \\
\hline Cutbirth et al. & 1998 & - & - & $100(10-\mathrm{CR})^{* *}$ & - & - \\
\hline Hoppenreijs et al. & 1998 & - & - & - & - & $259(40-\mathrm{CR})$ \\
\hline Hwang et al. & 2004 & $\mathrm{U}$ & $\mathrm{U}$ & $\mathrm{U}$ & $\mathrm{U}$ & $39(17-\mathrm{CR})$ \\
\hline
\end{tabular}

$\mathrm{U}=$ Uninformed; $\mathrm{F}=$ Female; $\mathrm{M}=$ Male; $\mathrm{BSSRO}=$ bilateral sagittal split ramus osteotomy; $\mathrm{WF}=$ Wire Fixation; $\mathrm{RF}=$ Rigid fixation; $\mathrm{NA}=$ data on type of fixation not given. 


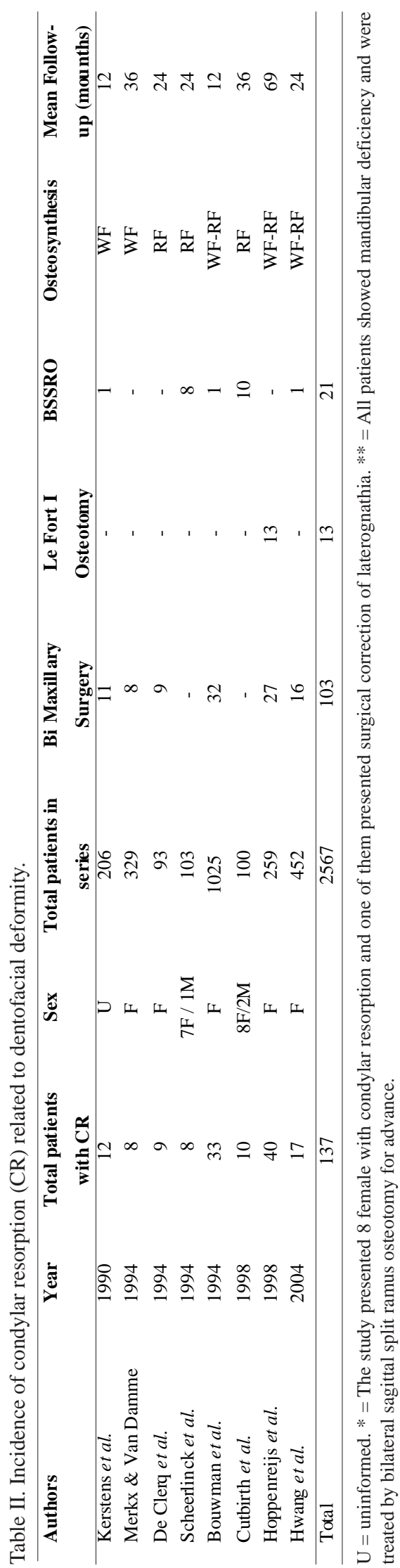

according to the inclusion/exclusion criteria, 10 articles qualified (inter-rater $\mathrm{K}=0.937$ ) for the final review. However, the same patients compose 3 selected studies. In this case, only the study with longer follow-up was considered. Thus, a total of 8 papers were selected (Table I).

Follow-Up Period. The range of follow-up period was 12 months to 69 months. Two studies showing the minimum time of follow-up according to the inclusion criteria; two studies presented 24 months; two studies presented 36 months and one long-term follow-up (69 months).

Sociodemographic considerations. The total number of patients included in the systematic review was 2567. In $137(5,3 \%)$ patients was observed CR. For each research, the sample size ranged from 93 to 1025 patients and the age ranged was between 14 and 46 years. Kertens et al., (1990) did not specify the gender of the 12 patients with CR in his sample. However, considering the other seven researches was observed that the $97.6 \%$ (122) with CR was female. This suggests that female patients have a greater predisposition to $\mathrm{CR}$.

Dentofacial Deformity. There was a significant correlation between the characteristic of dentofacial deformity and condylar resorption after orthognathic surgery. CR was observed in 118 (21.8\%) of 541 patients with absolute mandibular deficiency (high mandibular plane angle); 18 (2.2\%) of 828 patients with mandibular deficiency (low/normal plane angle) and one case with asymmetry (Table II).

Orthognathic Surgery. The CR patient was observed in three different groups. We found a higher prevalence of CR in 103 patients (75.2\%) with bi maxillary surgery, followed by 21 cases with bilateral sagittal split ramus osteotomy (15.3\%) and 13 cases $(9.5 \%)$ with only Le Fort I osteotomy. For osteosynthesis relations, CR was found in patient with wire fixation and rigid fixation and some research presented patient with intermaxillary fixation for 4-6 weeks. For the patient analysis, it was observed that in 67 with wire fixation (9.9\% of total patients with wire fixation) CR was present and in 56 patients with rigid fixation (13\% of total patients with rigid fixation) $\mathrm{CR}$ was observed. For the record it was important that Hwang et al., did not specify the osteosynthesis used in the sample of analysis (Table III).

Table III. Incidence of condylar resorption (CR) related to osteosynthesis.

\begin{tabular}{lccc}
\hline Authors & Year & Wire Fixation & Rigid Fixation \\
\hline Kerstens et al. & 1990 & $206(12-\mathrm{CR})$ & - \\
Merkx \& Van Damme & 1994 & $329(8-\mathrm{CR})$ & - \\
De Clerq et al. & 1994 & - & $93(9-\mathrm{CR})$ \\
Scheerlinck et al. & 1994 & - & $103(8-\mathrm{CR})$ \\
Bouwman et al. & 1994 & $91(24-\mathrm{CR})$ & $67(8-\mathrm{CR})$ \\
Cutbirth et al. & 1998 & - & $100(10-\mathrm{CR})$ \\
Hoppenreijs et al. & 1998 & $50(14-\mathrm{CR})$ & $67(13-\mathrm{CR})$ \\
Hwang et al. & 2004 & $\mathrm{U}(9-\mathrm{CR})$ & $\mathrm{U}(8-\mathrm{CR})^{*}$ \\
\hline Total & - & $676(67-\mathrm{CR})$ & $430(56-\mathrm{CR})$ \\
\hline
\end{tabular}

$\mathrm{U}=$ uninformed. $*=$ Bilateral sagittal split ramus osteotomy was treated by bicortical screws in 10 cases and monocortical screw / miniplate in 7 cases. Intraosseous wire fixation was used to stabilize the maxillary osteotomy in 9 cases and screw/ miniplates in 7 cases. 


\section{DISCUSSION}

A lack of randomized clinical trials and prospective studies makes a meta-analysis study impossible. To increase the power of this systematic review, it would be necessary to include only randomized, clinical trials, prospective multicenter articles, or prospective clinical trial. The huge number of possible articles was reduced because of inclusion and exclusion criteria that were thought to promote the possible risk factors of condylar resorption after orthognathic surgery.

Sex and age variables. The incidence of condylar resorption after orthognathic surgery in this systematic review showed ranges from $3 \%$ to $15 \%$. However, only two authors examine the incidence the $\mathrm{CR}$ in all types of dysgnathias with ranges from $3 \%$ to $6 \%$ (Kerstens et al.; Bouwman et al.). In two studies (Scheerlinck; Cutbirth et al., 1998) only cases with patients with mandibular deficiency (low/normal mandibular plane angle) were examined showed ranges from $8 \%$ to $10 \%$. Hoppenreijs et al. include only patients with absolute mandibular deficiency (high mandibular plane angle) showed $15 \%$ with CR. Other authors included in the systematic review (Merkx \& Van Damme; De Clercq et al., 1994; Hwang et al., 2004) did not specify all types dentofacial deformity examined of the study, but reported CR between $3 \%$ to $10 \%$.

The interpretation of the high proportion of females with condylar resorption following orthognathic surgery is controversial. Cutbirth el al., found that sex did not have a statistically significant effect on the incidence of condylar resorption after mandibular advancement. They stated that more women showed resorption than men because more women underwent surgery. In others studies, however, the overwhelming majority of previously reported cases of condylar resorption following orthognathic surgery were females (Hoppenreijs et al.; Merkx \& Van Damme). However, 2 studies in this systematic review showed male with CR, showing that CR is not only of female (Scheerlinck et al.; Cutbirth et al.). There was no correlation between CR and age of patient.

TMJ dysfunction variables. TMJ dysfunction has been study in different clinical situation and is a fact that an important part of patient with facial deformities present a TMJ pathology (Dujoncquoy et al., 2010) and pre surgical TMJ dysfunction can contribute to the development of postoperative condylar resorption (Cutbirth et al.). In this direction, Wolford et al., (2003) showed that a high percentage of patient with TMJ pathology after orthognathic surgery presented a significant worsening of the TMJ dysfunction.
In this systematic review, 2 studies showed preoperative TMJ dysfunction (Scheerlinck et al.; Cutbirth et $a l$.) and other 3 studies no reported this issue. For Hoppenreijs et al., there were no significant correlations between intensity of preoperative TMJ sounds and radiological condylar changes, or between mouth opening and condylar changes. However, an increased rate to TMJ dysfunction after orthognathic surgery has been reported in patients with mandibular hypoplasia and a high mandibular plane angle (Kerstens et al.; De Clercq et al.), although Hoppenreijs et al., and Cutbirth et al., reported that patients with large advancements and preoperative joint symptoms appear to be at risk for CR. The data obtained between TMJ dysfunction and CR is unable to draw definite conclusions.

Condylar remodeling is a physiologic process that aims to adapt the structure of the temporo-mandibular joint (TMJ) to meet the functional demands. It is based on an interaction between the mechanical forces sustained by the TMJ and the adaptive capacities of the condyle. Orthognathic surgery can sometimes be responsible for an excessive physical stress to the articular surfaces. In these cases, normal functional condylar remodeling shifts to the process of progressive condylar resorption.

Facial deformity and surgery variables. Facial deformity and condylar resorption after orthognathic surgery showed a significant correlation, specifically, the height of the mandibular plane. In 6 of 8 selected studies (Hoppenrejis et al.; Kerstens et al.; Bouwman et al.; Merkx \& Van Damme; De Clercq et al.; Hwang et al., 2004), 541 patients who have absolute mandibular deficiency (high mandibular plane angle), 118 (21.8\%) showed CR. This correlation may be explained by the change of loading after the correction of this type dentofacial deformity. Mechanical loading during or after BSSO could limited the blood flow to the condyle and capsule, been contributing factors to the CR (Hoppenreijs et al.). The relative reduction in condylar vascular supply may trigger the course of events in some patients; however, $78.2 \%$ of the patients who have absolute mandibular deficiency showed no CR.

The mandible or bi maxillary surgery could modify the condylar position and be a factor for CR; in mandible surgery, statistical differences were not observed between the pre-surgical and post-surgical position of condyle (Ueki et al., 2002; Fang et al., 2009; Hackney et al., 1989; Will et al., 1984) but this difference could be a clinical significance in the postoperative condition. On the other hand, Baek et al. (2006) showed that in asymmetric movement (using 
sagittal split ramus osteotomy) the condylar position was the same after and before of surgery but with differences in inclination of condylar head of major and minor movement; this situation can be an explanation for different load on the condylar head and consecutively bone reabsorption.

Six studies showed a higher incidence of CR in bi maxillary osteotomy (Hoppenreijs et al.; Kersens et al.; Bouwman et al.; Merkx et al.; De Clercq et al.; Hwang et al., 2004), 103 (75.2\%) patients with bimaxillary osteotomy developed CR. This osteotomy is generally used to correct deformities with high mandibular plane angle associated to change counterclockwise of occlusal plane. In this surgery, with the rotation of the mandible proximal segment rotation of the condylar head occurs (Hwang et al., 2004). This leads to exposure of the less dense, previously unloaded anterior-superior condylar surface to compressive loads (O’Ryan \& Epker). When the condylar neck is inclined posteriorly, the less loaded anterior-superior area of the condyle is more exposed to loading and subjected to resorption (Hwang et al., 2004). However, the relationship between the change mandibular plane (MP) angle and CR is not sufficiently clear. On the other hand, in a systematic review, Bouwman et al., reported no correlation between intermaxillary fixation for a period of (4-6 weeks) and CR when wire fixation or rigid fixation was used.

Finally, we can conclude that condylar resorption following orthognathic surgery is a multifactorial phenomenon, and some of the risk factors are interrelated. In the present systematic review, risk factors were female patients with absolute mandibular deficiency and high mandibular plane angle submitted bimaxillary osteotomy associated with change in occlusal plane (counterclockwise). It is recommended the patients with these characteristics should be given explicit preoperative information on the risk of condylar resorption with skeletal relapse.

The application of this current review is limited by the heterogeneity of the study protocols and data analysis techniques adopted in the studies considered. More information about etiology and the natural course of condylar changes in untreated patients is desirable. Prospective studies are necessary to gain more insight into the pathophysiology of condylar resorption after orthognathic surgery. Further systematic reviews and a meta-analysis of the data from the various studies are desirable.

DE MORAES, P. H.; RIZZATI-BARBOSA, C. M.; OLATE, S.; MOREIRA, R. W. F. \& DE MORAES, M. Reabsorción condilar después de cirugía ortognática: Una revisión sistemática. Int. J. Morphol., 30(3):1023-1028, 2012.

RESUMEN: El objetivo de esta investigación fue evaluar los factores de riesgo asociados a reabsorción condilar (RC) posterior a cirugía ortognática. Fue realizada una revisión sistemática con una búsqueda de la literatura realizada en bases de dato electrónicos como PubMed, MedLine, Ovid, Cochrane Library buscando actual evidencia en la literatura mundial; artículos relevantes fueron seleccionados según los criterios de inclusión y exclusión, comparando sus resultados. Ocho artículos (tiempo de seguimiento de 12 a 69 meses) fueron incluidos. Se observó una muestra de 2567 pacientes con cirugía mandibular o bimaxilar con una edad de entre 14 y 46 años. En 137 pacientes (5,3\%) se observó reabsorción condilar, siendo el 97,6\% (122 casos) de sexo femenino. La RC fue observada n 118 casos de deficiencia mandibular con un plano mandibular alto (cirugía de avance mandibular). La RC estuvo presente principalmente en cirugías bimaxilares con 103 casos afectados (75,2\%) y solo dos artículos evidenciaron análisis previo de disfunción de ATM. Actualmente la evidencia en RC es limitada pero fundamenta que mujeres con deficiencia mandibular y alto plano mandibular sometidas a cirugía bimaxilar con alteración del plano oclusal (giro horario) son asociadas a la reabsorción condilar después de la cirugía ortognática.

PALABRAS CLAVE: Reabsorción condilar; Cirugía ortognatica; Disfunción de ATM.

\section{REFERENCES}

Arnett, G. W. \& Tamborello, J. A. Progressive class II development: female idiopathic condylar resorption. Oral Maxillofac. Surg. Clin. North. Am., 2:699-716, 1990.

Arnett, G. W.; Milam, S. B. \& Gottesman, L. Progressive mandibular retrusion - idiopathic condylar resorption. Part I. Am. J. Orthod. Dentofac. Orthop., 110(2):8-15, 1996a

Arnett, G. W.; Milam, S. B. \& Gottesman, L. Progressive mandibular retrusion - idiopathic condylar resorption. Part II. Am. J. Orthod. Dentofac. Orthop., 110(2):117-27, 1996b
Baek, S. H.; Kim, T. K. \& Kim, M. J. Is there any difference in the condylar position and angulation after asymmetric mandibular setback? Oral Surg. Oral Med. Oral Pathol. Oral Radiol. Endod., 101(2):155-63, 2006.

Bouwman, J. P.; Kerstens, H. C. \& Tuinzing, D. B. Condylar resorption in orthodontic surgery: the role of intermaxillary fixation. Oral Surg. Oral Med. Oral Pathol., 78(2):138-41, 1994.

Cutbirth, M.; Van Sickels, J. E. \& Thrash, W. J. Condylar resorption 
after bicortical screw fixation of mandibular advancement. $J$. Oral Maxillofac. Surg., 56(2):178-82, 1998.

de Bont, L. G. \& Stegenga, B. Pathology of temporomandibular joint internal derangement and osteoarthrosis. Int. J. Oral Maxillofac. Surg., 22(2):71-4, 1993.

De Clercq, C. A.; Neyt, L. F.; Mommaerts, M. Y.; Abeloos, J. V. \& De Mot, B. M. Condylar resorption in orthognathic surgery: a retrospective study. Int. J. Adult. Orthodon. Orthognath. Surg., 9(3):233-40, 1994.

de Mol van Otterloo, J. J.; Dorenbos, J.; Tuinzing, D., B. \& van der Kwast, W. A. TMJ performance and behaviour in patients more than 6 years after Le Fort I osteotomy. Br. J. Oral Maxillofac. Surg., 31(2):83-6, 1993.

Dujoncquoy, J. P.; Ferri, J.; Raoul, G. \& Kleinheinz, J. Temporomandibular joint dysfunction and orthognathic surgery: a retrospective study. Head Face Med., 6:27, 2010.

Fang, B.; Shen, G. F.; Yang, C.; Wu, Y.; Feng, Y. M.; Mao, L. X. \& Xia, Y. H. Changes in condylar and joint disc positions after bilateral sagittal split ramus osteotomy for correction of mandibular prognathism. Int. J. Oral Maxillofac. Surg., 38(7):726-30, 2009.

Hackney, F.; Van Sickels, J. E.; Nummikoski, P. V. Condylar displacement and temporomandibular joint dysfunction following bilateral sagittal split osteotomy and rigid fixation. J. Oral Maxillofac. Surg., 47:223-7, 1989.

Hoppenreijs, T. J.; Freihofer, H. P.; Stoelinga, P. J, Tuinzing, D. B. \& van't Hof, M. A. Condylar remodelling and resorption after Le Fort I and bimaxillary osteotomies in patients with anterior open bite: a clinical and radiological study. Int. J. Oral Maxillofac. Surg., 27(2):81-91, 1998.

Huang, Y. L.; Pogrel, M. A. \& Kaban, L. B. Diagnosis and management of condylar resorption. J. Oral Maxillofac. Surg., 55(2):114-9, 1997.

Hwang, S. J.; Haers, P. E. \& Sailer, H. F. The role of a posteriorly inclined condylar neck in condylar resorption after orthognathic surgery. J. Craniomaxillofac. Surg., 28(2):85-90, 2000 a.

Hwang, S. J.; Haers, P. E.; Zimmermann, A.; Oechslin, C.; Seifert, B. \& Sailer, H. F. Surgical risk factors for condylar resorption after orthognathic surgery. Oral Surg. Oral Med. Oral Pathol. Oral Radiol. Endod., 89(5):542-52, 2000 b.

Hwang, S. J.; Haers, P. E.; Seifert, B. \& Sailer, H. F. Non-surgical risk factors for condylar resorption after orthognathic surgery. J. Craniomaxillofac. Surg., 32:103-11, 2004.

Kerstens, H. C.; Tuinzing, D. B.; Golding, R. P. \& Van der Kwast, W. A. Condylar atrophy and osteoarthrosis after bimaxillary surgery. Oral Surg. Oral Med. Oral Pathol., 69(3):274-80, 1990.
Merkx, M. A. \& Van Damme, P. A. Condylar resorption after orthognathic surgery: evaluation of treatment in 8 patients. $J$. Craniomaxillofac. Surg., 22(1):53-8, 1994.

Moore, K. E.; Gooris, P. J. \& Stoelinga, P. J. The contributing role of condylar resorption to skeletal relapse following mandibular advancement surgery. Report of 5 cases. J. Oral Maxillofac. Surg., 49(5):448-60, 1991.

O'Ryan, F. \& Epker, B., N. Temporomandibular joint function and morphology: Observation on the spectra of normalcy. Oral Surg. Oral Med. Oral Pathol., 58(3):272-9, 1984

Phillips, R. M. \& Bell, W. H. Atrophy of mandibular condyles after sagittal ramus split osteotomy: report of a case. J. Oral Surg., 36(1):45-9, 1978.

Scheerlinck, J. P.; Stoelinga, P. J.; Blijdorp, P. A.; Brouns, J. J. \& Njjs, M. L. Sagittal split advancement osteotomies stabilized with miniplates: a 2-5 year follow-up. Int. J. Oral Maxillofac. Surg., 23(3):127-31, 1994.

Ueki, K.; Marukawa, K.; Nakagawa, K. \& Yamamoto, E. Condylar and temporal joint disc positions after mandibular osteotomy for prognathism. J. Oral Maxillofac. Surg., 60(12):1424-34, 2002

Wolford, L. M.; Retche-Fischel, O. \& Mehra, P. Changes in temporomandibular joint dysfunction after orthognathic surgery. J. Oral Maxillofac. Surg., 61(6):655-61, 2003.

Will, L. A.; Joondeph, D. R.; Hohl, T. H. \& West, R. A. Condylar position following mandibular advancement: its relationship to relapse. J. Oral Maxillofac. Surg., 42(9):578-88, 1984.
Correspondence to:

Prof. Dr. Sergio Olate

Division of Oral and Maxillofacial Surgery

Faculty of Dentistry

Universidad de La Frontera

Claro Solar No 115

Temuco

CHILE

Phone: 56-45-325000

Email: solate@ufro.cl

Received : 10-11-2011

Accepted : 03-04-2012 